\title{
On the genus Bursaphelenchus Fuchs, 1937 (Nematoda: Parasitaphelenchinae) associated with wood and insects from declining forest trees in the Czech Republic
}

\author{
V. Čermák ${ }^{1}$, P. Vieira ${ }^{2}$, V. Gaar ${ }^{1}$, M. Čudejková ${ }^{1}$, J. Foit ${ }^{3}$, M. Zouhar ${ }^{4}$, O. Douda ${ }^{5}$ and M. Mota ${ }^{2}$ \\ ${ }^{1}$ Division of Diagnostics, State Phytosanitary Administration, Šlechtitelů 773/23, Olomouc, 779 00, Czech Republic; ${ }^{2}$ Lab. Nematologia/ \\ ICAAM - Instituto de Ciências Agrárias e Ambientais Mediterrânicas, Universidade de Évora, Núcleo da Mitra, Ap. 94, 7002-554 Évora, \\ Portugal; ${ }^{3}$ Department of Forest Protection and Game Management, Mendel University in Brno, Zemădělská 3, Brno, 613 00, Czech \\ Republic; ${ }^{4}$ Department of Plant Protection, Czech University of Agriculture, Kamýcká 129, Praha-Suchdol, 165 00, Czech Republic; \\ ${ }^{5}$ Department of Entomology, Research Institute of Crop Production, Drnovská 507/73, Praha-Ruzyně, 161 06, Czech Republic; \\ ${ }^{6}$ Email: vaclav.cermak@srs.cz (for correspondence)
}

\begin{abstract}
Summary
An overview of the genus Bursaphelenchus in the Czech Republic is presented, based on a recent survey for monitoring the presence of the pinewood nematode, Bursaphelenchus xylophilus, as well as on previous reports of this genus in the country. In addition, we provide a morphological and molecular characterization of four Bursaphelenchus species (B. eremus, B. pinophilus, B. vallesianus and B. borealis) found during the monitoring programme for forest pests, conducted during 2006-2010, within the Moravian and Bohemian regions. Nematodes were extracted from over 1917 insects and 1493 wood samples collected from deciduous and coniferous trees exhibiting wilting and declining symptoms. Bursaphelenchus species were found only in $0.73 \%$ of insects and $0.47 \%$ of the total number of wood samples. Bursaphelenchus borealis and B. pinophilus dauer juveniles were found associated with the insect vectors Dryocetes autographus and Pityogenes bidentatus, respectively. While a total of seven Bursaphelenchus species are now reported from the Czech Republic, the status of $B$. xylophilus remains as absent.
\end{abstract}

\section{Introduction}

The detection of the pinewood nematode (PWN), Bursaphelenchus xylophilus (Steiner \& Buhrer, 1934) Nickle, 1970, in mainland Portugal and Madeira Island (Mota et al. 1999; Fonseca et al. 2012) marks one of the most recent introductions of an invasive species into pine forest ecosystems in Europe. More recently, three incursions have been reported from Spain as well (Abelleira et al. 2011; Robertson et al. 2011). Following the detection of the PWN in one of the member states of the European Union, all other members have been conducting specific programmes for the detection of this quarantine species in their own forests and strategic areas where the nematode could enter as a result of human activities (Anonymous 2007).

In the Czech Republic, coniferous forests are of high importance, occupying approximately $74 \%$ of the total forest area. Norway spruce (Picea abies L.) occupies $52.2 \%$ of the total forest area, followed by Scots pine (Pinus sylvestris L.) representing 17\% of that area (Anonymous 2009). The other coniferous areas together represent 5.1\% of the total area, distributed among larch (Larix decidua Miller, 3.9\%), fir (Abies alba Miller, 1\%) and other pine species that together represent no more than $0.2 \%$ (Pinus mugo Turra, P. nigra Arnold and P. strobus L.). The remaining area (25\%) is occupied mostly by oak, beech, birch, hornbeam and alder species (Anonymous 2009). The potential introduction of the PWN in the Czech Republic could create a high impact on the country's forest resources, as the major coniferous species $(P$. abies and $P$. sylvestris) are hosts of the PWN (Evans et al. 1996).

Following EPPO recommendations, medium- and long-term monitoring for quarantine species are fairly well established in the country. To detect a hypothetical introduction of the PWN, several surveys have been conducted in the past years. Up to now, the PWN has not been detected in Czech forests (Běhalová 2006). During 2006-2011, a new survey was performed in several areas of Moravia and Bohemia, for monitoring the presence of Bursaphelenchus species in these regions. During this survey, several species were identified. Currently, the information about the genus Bursaphelenchus in the Czech Republic is very scarce based on single reports without any detailed morphological or molecular characterization of the species identified. Herein, we present an updated distribution of all Bursaphelenchus species reported for the country, including a morphological and molecular characterization of the Bursaphelenchus species found during our survey. Furthermore, a list of the most common insect species found associated with wilting or declining symptomatic trees is also provided, including the insect-associated nematodes.

\section{Materials and methods}

\subsection{Wood sampling and nematode extraction}

During 2006-2011, a survey was conducted in the Moravian and Bohemian regions of the Czech Republic as part of a general survey for forest quarantine species, including B. xylophilus. A total of 1493 wood samples were collected from decidu- 
Table 1. Occurrence of Bursaphelenchus species in the Czech Republic.

\begin{tabular}{|c|c|c|c|c|c|c|}
\hline Bursaphelenchus sp. & Location & $\begin{array}{l}\text { Elevation } \\
\text { (m a.s.l.) }\end{array}$ & Region & Host & Insect vector & Publication \\
\hline B. borealis & N49 06.574 E13 30.340 & 857 & Svojše (Bohemia) & Picea abies & $\begin{array}{l}\text { Dryocetes } \\
\text { autographus }\end{array}$ & This study \\
\hline \multirow[t]{2}{*}{ B. eremus } & - & 190 & Bačov (Bohemia) & Quercus robur & $\begin{array}{l}\text { Scolytus } \\
\text { intricatus }\end{array}$ & $\begin{array}{l}\text { Kubátová } \\
\text { et al. } \\
2000 \text {; }\end{array}$ \\
\hline & N50 37.859, E15 05.269 & 329 & Sychrov (Bohemia) & Quercus spp. & - & This study \\
\hline B. fungivorus & - & - & - & Coniferous bark & - & $\begin{array}{l}\text { Braasch et al. } \\
\text { 2002; }\end{array}$ \\
\hline B. hofmanni & - & - & - & $\begin{array}{l}\text { Imported } \\
\text { coniferous wood }\end{array}$ & - & $\begin{array}{l}\text { (Tomiczek \& } \\
\text { Braasch, } \\
\text { unpublished), } \\
\text { in Braasch } \\
\text { 2001; }\end{array}$ \\
\hline B. mucronatus & - & - & - & Pinus sylvestris & - & $\begin{array}{l}\text { (Tomiczek, } \\
\text { pers. } \\
\text { comm.), in } \\
\text { Braasch 2001 }\end{array}$ \\
\hline \multirow[t]{2}{*}{ B. pinophilus } & N48 53.873, E17 12.360 & 192 & Rohatec (Moravia) & Pinus sylvestris & \multirow[t]{2}{*}{$\begin{array}{l}\text { Pythiogenes } \\
\text { bidentatus }\end{array}$} & This study \\
\hline & N48 53.871, E17 12.652 & 167 & Bzenec (Moravia) & Pinus sylvestris & & This study \\
\hline \multirow[t]{2}{*}{ B. vallesianus } & N49 58.995, E 1349.349 & 490 & Karlova ves (Bohemia) & Pinus sylvestris & - & This study \\
\hline & N48 53.879, E17 11.127 & 200 & Rohatec (Moravia) & Pinus sylvestris & - & $\begin{array}{l}\text { Gaar et al. } \\
2006\end{array}$ \\
\hline
\end{tabular}
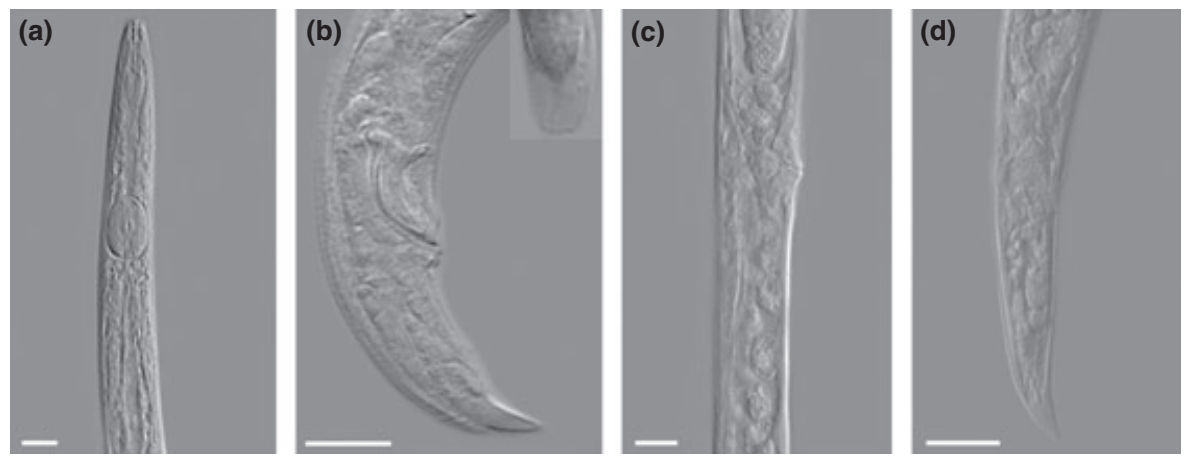

Fig. 1. Light micrograph of Bursaphelenchus eremus collected from wood. (a) Anterior region. (b) Male tail and bursa (ventral view). (c) Vulva region. (d) Female tail. Scale bars $=10 \mu \mathrm{m}$.

ous and coniferous trees (20-100 years old) exhibiting wilting and decline symptoms (pine, 1222; spruce, 129; larch, 6; oak, 33; orchard trees, 39; other deciduous trees, 64). Samples (approximately $50 \mathrm{~g}$ each) were collected from the trunk and branches of all sizes, displaying signs of the presence of insects (insect holes, galleries). Samples were collected after tree debarking and obtained using a drill or with the use of a chisel. On average, wood samples were incubated for 10 days at $27^{\circ} \mathrm{C}$, within sealed plastic bags to avoid moisture loss. Nematodes were extracted using the 'tray method' technique over $48 \mathrm{~h}$ at room temperature (Whitehead and Hemming 1965). The extracted nematodes were killed and fixed in $4 \%$ formalin and transferred to pure glycerine according to Seinhorst (1959). Using a light microscope (Olympus, Bx50), morphological and morphometric analyses were performed from specimens directly collected from wood samples. Nematode identification was based on observations of the main morphological features for the genus Bursaphelenchus, particularly spicule shape, number and position of caudal papillae, number of incisures in the lateral field, presence of a vulval flap and female tail shape (Ryss et al. 2005; Braasch et al. 2009). For each species of Bursaphelenchus found, 10-20 specimens collected directly from wood samples were used to generate the respective morphological and morphometric data. Wood samples containing a sufficient number of Bursaphelenchus specimens were transferred and maintained in cultures of Botrytis cinerea Pers. ex Ft., growing in 5\% malt extract agar (MEA).

\subsection{Insect sampling and associated nematode identification}

Within the same period, 1917 bark- and wood-boring insects were collected from the same declining or symptomatic trees and screened for the presence of Bursaphelenchus species. Bark and longhorn adult beetles were captured with soft entomological forceps after debarking parts of the trunk displaying symptoms of insect attack and kept in plastic tubes at $7^{\circ} \mathrm{C}$ until dissection. In addition, intact trunk sections cut from affected trees that contained potential longhorn beetle larvae were also 

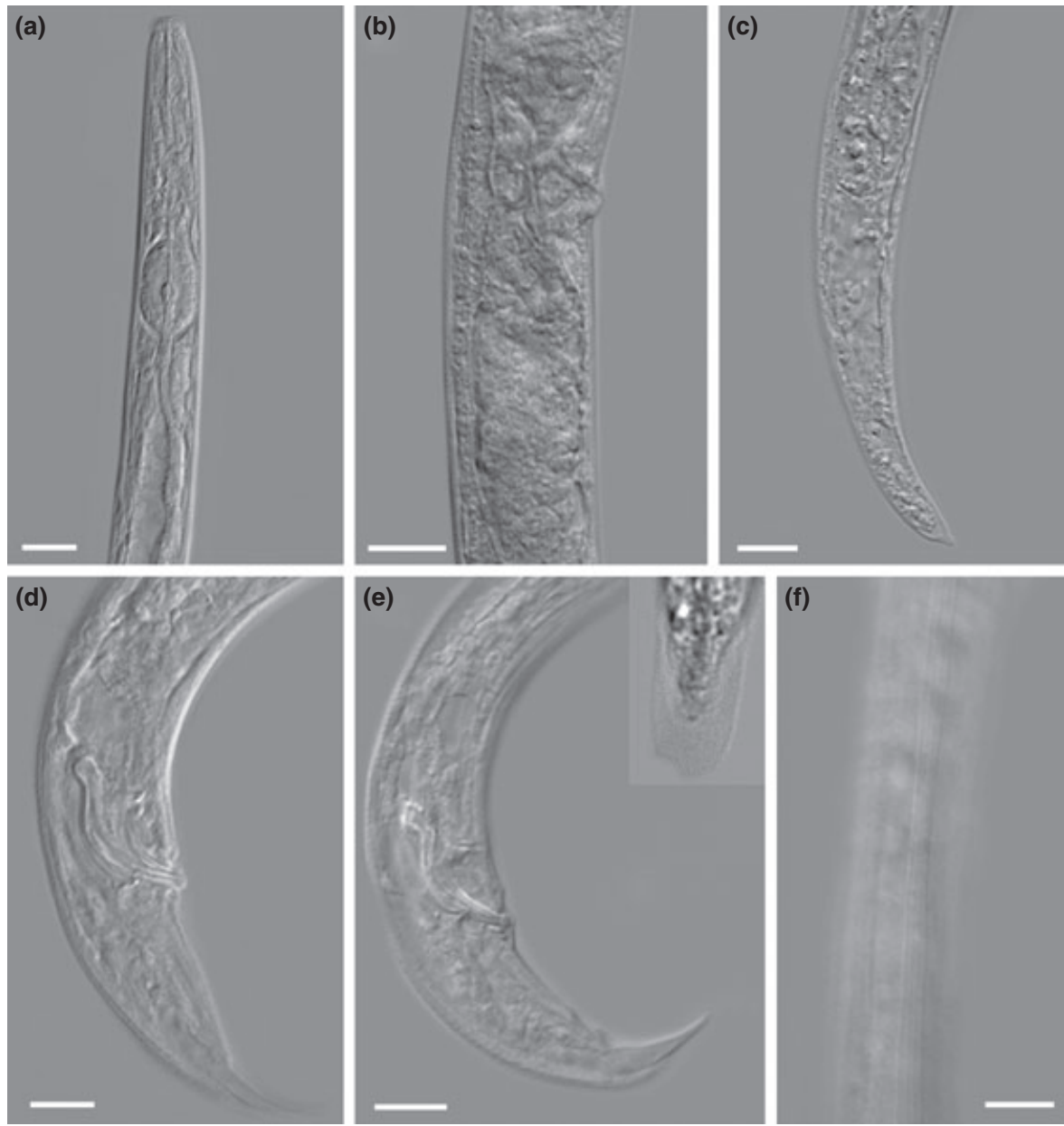

Fig. 2. Light micrograph of Bursaphelenchus pinophilus collected from wood. (a) Anterior region. (b) Vulva region. (c) Female tail. (d-e) Male tail, with ventral view of the bursa in (e). (f) Lateral field with four incisures. Scale bars $=10 \mu \mathrm{m}$.

collected. These sections were kept in the laboratory at room temperature until emergence of the insects. All adult insects were identified to species level. Each adult insect was individually dissected in water and examined for the presence of nematodes. All nematodes resembling dauer juveniles of the genus Bursaphelenchus were collected and identified using ITS-RFLP analysis, as described later. All other nematodes were mounted in temporary slides and identified up to the genus level.

\subsection{Molecular analysis}

Nematodes (1-15) were collected into a drop of demineralized water in a 1.5-ml Eppendorf tube and stored at $-20^{\circ} \mathrm{C}$ for subsequent molecular characterization. Genomic DNA was extracted using a High Pure PCR Template Preparation Kit (Roche, Basel, Switzerland) according to the manufacturer's protocol for isolation of nucleic acids from mammalian tissues. DNA was eluted in $50 \mu \mathrm{l}$ of pre-heated elution buffer. The target region containing the ITS1, 5.8S and ITS2 of ribosomal DNA was amplified by PCR using the forward primer 5'-CGTAACAAGGTAGCTGTAG-3' (Ferris et al. 1993) and reverse primer 5'-TTTCACTCGCCGTTACTAAGG-3' (Vrain 1993). Each PCR was performed in a total volume of $50 \mu \mathrm{l}$, containing $1 \times$ PCR buffer (75 mм Tris- $\mathrm{HCl}$ pH 9,0, $50 \mathrm{~mm} \mathrm{KCl,} 20$ mм $\left.\left(\mathrm{NH}_{4}\right)_{2} \mathrm{SO}_{4}\right), 4 \mathrm{~mm} \mathrm{MgCl}_{2}, 400 \mu \mathrm{m}$ dNTPs, 600 nм of each primer, 2 $\mathrm{U}$ of Biotools DNA polymerase (Biotools, Madrid, Spain) and $10 \mu \mathrm{l}$ of template DNA. DNA was amplified in a Mastercycler Gradient thermocycler (Eppendorf) or Thermal XP Cycler (Bioer Technology Co., LTD, Hangzhou, China) using an initial denaturation step for $5 \mathrm{~min}$ at $94^{\circ} \mathrm{C}$, followed by 40 reaction cycles of denaturation for $1 \mathrm{~min}$ at $94^{\circ} \mathrm{C}$, annealing for 1 min at $55^{\circ} \mathrm{C}$ and extension for $2 \mathrm{~min}$ at $72^{\circ} \mathrm{C}$, with a final extension for $10 \mathrm{~min}$ at $72^{\circ} \mathrm{C}$. Ten microlitres of PCR product was analysed by electrophoresis using ethidium bromide stained 1.5\% agarose gel in TBE buffer, and size of the products was compared with 100-bp DNA ladder (Promega Corporation, Madison, WI, USA). Six microlitres of the amplified DNA was digested for at least $2 \mathrm{~h}$ at $37^{\circ} \mathrm{C}$, using $2.5 \mathrm{U}$ of each of the five enzymes (AluI, HaeIII, Hinfl, MspI and RsaI) in the total volume of $10 \mu \mathrm{l}$. These five restriction enzymes are known to generate species-specific ITS-RFLP profiles for Bursaphelenchus species (Burgermeister et al. 2009). The restriction fragments were resolved by electrophoresis in a 3\% (w/v) agarose polyacrylamide gel in TBE buffer and stained with ethidium bromide. The size of the fragments was estimated by comparing with 100-bp DNA ladder (Promega Corporation). 

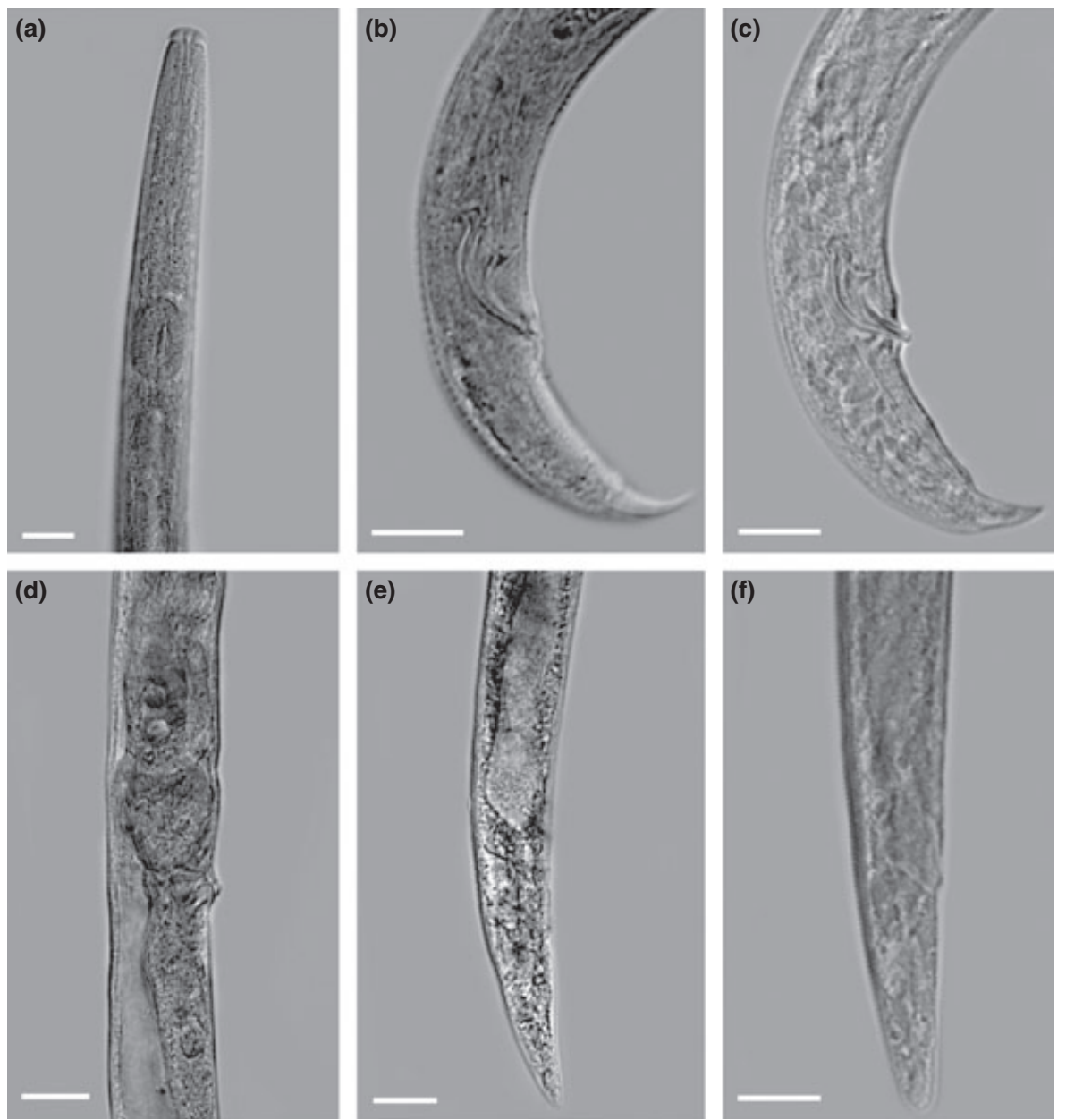

Fig. 3. Light micrograph of Bursaphelenchus vallesianus collected from wood. (a) Anterior region. (b-c) Male tail. (d) Vulva region. (e-f) Female tail. Scale bars $=10 \mu \mathrm{m}$.

\section{Results}

The geographical distribution of the Bursaphelenchus species found during this survey, as well as the species previously reported from the Czech Republic is summarized in Table 1. From the 1493 wood samples collected from the Moravia and Bohemia regions, only five samples contained Bursaphelenchus species (Table 1).

\subsection{Bursaphelenchus spp. - Tree host association}

A total of three different Bursaphelenchus species were identified from the 1493 wood samples collected from trees. These were B. eremus Rühm, 1956 (Fig. 1), B. pinophilus Brzeski and Baujard 1997 (Fig. 2), and B. vallesianus Braasch, Shönfeld, Polomski \& Burgermeister, 2004 (Fig. 3). The morphological (Figs. 1-3) and morphometric data (Table 2) determined were generally in agreement with the respective original descriptions. B. eremus is characterized by short spicules (Fig. 1b), the presence of seven caudal papillae on males, three lateral incisures, females with no vulval flap (Fig. 1c), conical and gradually tapering female tail (Fig. 1d). Both B. pinophilus and B. vallesianus had stout and curved spicules, with prominent rostrum and condylus (Figs $2 \mathrm{~d}$, e and $3 \mathrm{~b}, \mathrm{c}$, respectively), the presence of seven caudal papillae, four lateral incisures (Fig. 2f) and females with a small vulval flap (Figs $2 \mathrm{~b}$ and $3 \mathrm{~d}$, respectively). Whereas B. pinophilus females have a more pointed and conoid tail (Fig. 2c), sometimes mucronate, B. vallesianus females present a conical, gradually tapering tail (Fig. 3e, f).

\subsection{Insect-Nematode association}

The 1917 insects collected from the declining trees were distributed among 13 different species, belonging to the families Buprestidae, Cerambycidae and Curculionidae. Nematodes were only detected in insects belonging to the subfamily Scolytinae (Curculionidae, $0.73 \%$ of the total number of insects collected), including two species of the genus Bursaphelenchus (Table 3), one of which was also detected in our wood samples. Bursaphelenchus borealis was isolated from several 


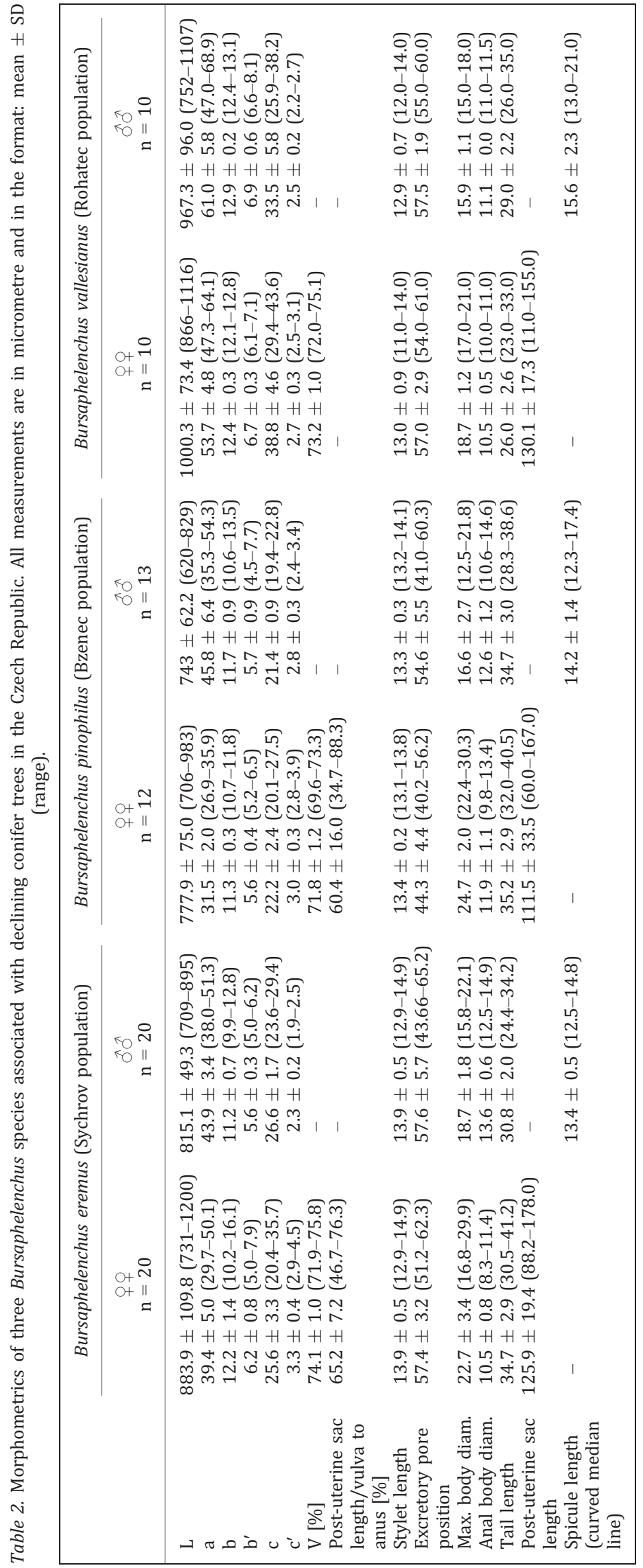


Table 3. Bark- and wood-boring insects collected from declining and symptomatic trees from Bohemia and Moravia regions and respective associated nematodes.

\begin{tabular}{|c|c|c|c|}
\hline Insect species & $\begin{array}{l}\text { Examined } \\
\text { specimens }\end{array}$ & $\begin{array}{l}\text { Specimens infested } \\
\text { with nematodes }\end{array}$ & Associated nematodes \\
\hline \multicolumn{4}{|l|}{ Buprestidae } \\
\hline Chrysobothris affinis & 1 & 0 & - \\
\hline Phaenops cyanea & 4 & 0 & - \\
\hline \multicolumn{4}{|l|}{ Cerambycidae } \\
\hline Monochamus galloprovincialis & 8 & 0 & - \\
\hline Plagionotus arcuatus & 1 & 0 & - \\
\hline Spondylis buprestoides & 3 & 0 & - \\
\hline \multicolumn{4}{|l|}{ Curculionidae } \\
\hline \multicolumn{4}{|l|}{ Molytinae } \\
\hline Pisodes piniphilus & 22 & 0 & - \\
\hline \multicolumn{4}{|l|}{ Scolytinae } \\
\hline Dryocetes autographus & 6 & 5 & $\begin{array}{c}\text { Bursaphelenchus borealis } \\
\text { Rhabditis }\end{array}$ \\
\hline Hylurgus ligniperda & 18 & 2 & Aphelenchoides \\
\hline Ips acuminatus & 80 & 23 & $\begin{array}{l}\text { Contorthylenchus } \\
\text { Cryptaphelenchus } \\
\text { Ektaphelenchus } \\
\text { Parasitaphelenchus } \\
\text { Parasitorhabditis } \\
\text { Parasitylenchus }\end{array}$ \\
\hline Ips duplicatus & 930 & 186 & $\begin{array}{l}\text { Cryptaphelenchus } \\
\text { Ektaphelenchus }\end{array}$ \\
\hline Orthotomicus proximus & 62 & 37 & $\begin{array}{l}\text { Cryptaphelenchus } \\
\text { Contorthylenchus. } \\
\text { Parasitaphelenchus } \\
\text { Parasitorhabditis }\end{array}$ \\
\hline Pityogenes bidentatus & 37 & 12 & Bursaphelenchus pinophilus \\
\hline Pityogenes chalcographus & 569 & 85 & $\begin{array}{c}\text { Cryptaphelenchus } \\
\text { Unidentified nematodes }\end{array}$ \\
\hline Pityophthorus pityographus & 34 & 5 & Unidentified nematodes \\
\hline Tomicus piniperda & 74 & 9 & $\begin{array}{l}\text { Contorthylenchus } \\
\text { Parasitorhabditis }\end{array}$ \\
\hline Tomicus minor & 68 & 12 & Parasitorhabditis \\
\hline Total & 1917 & 376 & \\
\hline
\end{tabular}

specimens of the bark beetle, Dryocetes autographus Ratzerburg, collected from symptomatic Picea abies trees. The dauer juveniles (Fig. 4) displayed three lateral incisures (Fig. 4a), slender body (Fig. 4b), dome-shaped head and a degenerated stylet (not clearly visible), oval metacorpus (Fig. 4e), with a variable conical tail (Fig. 4c, d). Our molecular analyses confirmed the identification of these specimens as B. borealis Korentchenko 1980 (Fig. 6).

Dauer juveniles of B. pinophilus were found associated with Pityogenes bidentatus (Herbst) (Čermák et al. 2012), collected from declining P. sylvestris. The dauer juveniles (Fig. 5a) were morphologically very similar, displaying the typical dome-shaped head, indistinct stylet, and elongated conoid to digitate tail (Fig. 5b, d). The morphobiometric data for the dauer juveniles of both species are presented in Table 4.

In the case of Dryocetes autographus, Ips acuminatus (Gyllenhal), Ips duplicatus (Sahlberg), Orthotomicus proximus Eich., Pityogenes chalcographus (L.) and Tomicus piniperda (L.), more than one nematode genus were carried by these insects (Table 3).

\subsection{Molecular characterization}

For each species of Bursaphelenchus that was collected in this study, a molecular characterization was performed using the ITS1, 5.8S and ITS2 region of the ribosomal DNA. The ITS-RFLP patterns obtained for all Bursaphelenchus species extracted from the declining trees or insect vectors, showed the same reference patterns established by Burgermeister et al. (2009) and therefore validated our morphological and morphometric characterization (Fig. 6).

\section{Discussion}

Information regarding the diversity of the genus Bursaphelenchus in the Czech Republic is scarce and occurs in a variety of brief reports or abstracts without any morphological or morphometric characterization of the different species reported. The objective of our survey was to see whether B. xylophilus occurred within the regions of Bohemia and Moravia. Four Bursaphelenchus species - B. eremus, B. pinophilus, B. vallesianus, and B. borealis - were isolated and characterized. Based on our findings and other available data, we discuss the present knowledge and distribution of the genus within the country. 


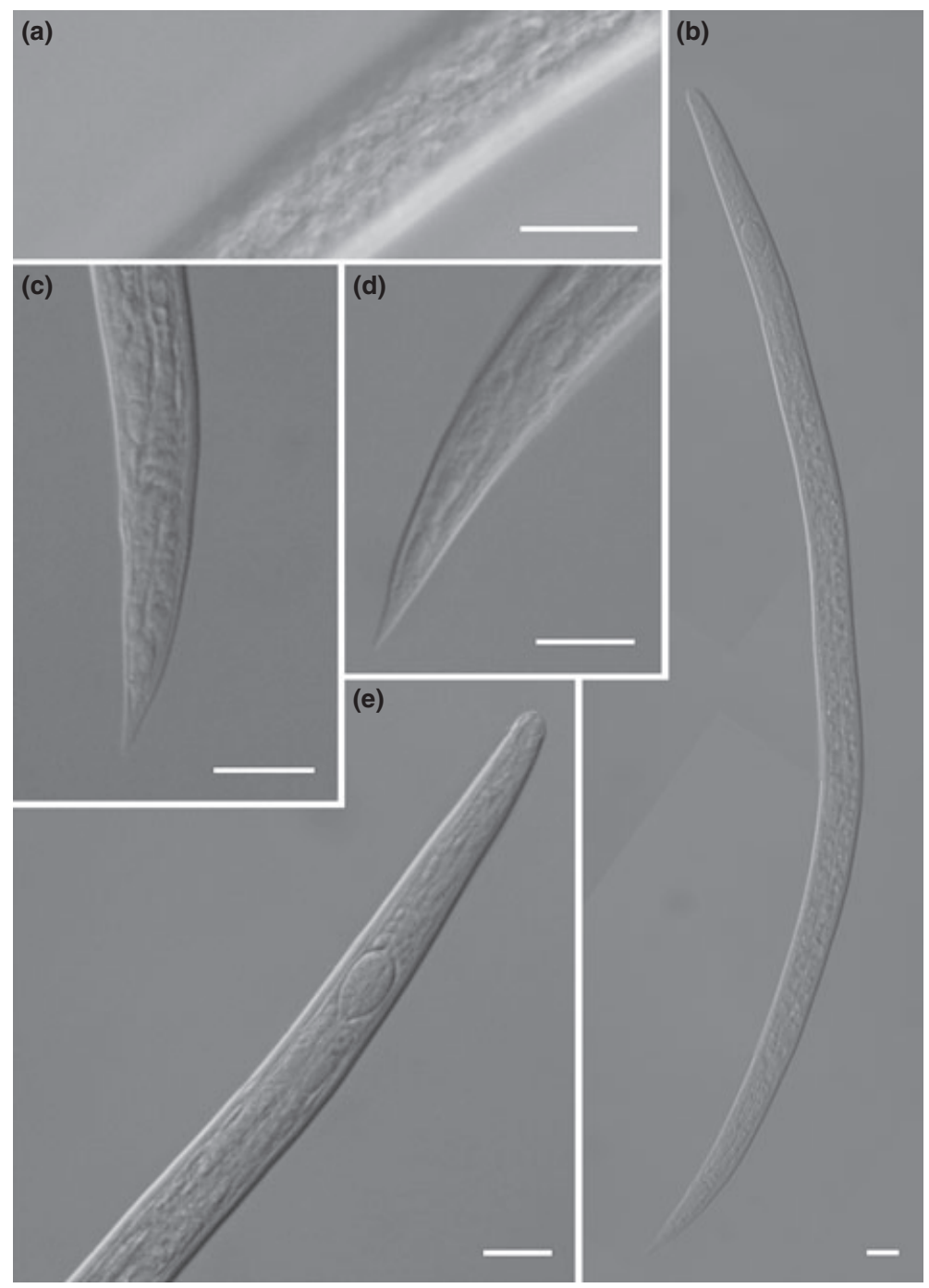

Fig. 4. Light micrograph of dauer juveniles of Bursaphelenchus borealis. (a) Lateral lines. (b) Whole dauer body. (c-d) Variation of dauer tails. (e) Anterior region. Scale bars $=10 \mu \mathrm{m}$.

The first report of the genus Bursaphelenchus for the Czech Republic was by Kubátová et al. (2000), who reported the association of B. eremus with the hyphomycetous microfungus Esteya vermicola and the bark beetle Scolytus intricatus (Ratzeburg), collected from several Quercus robur, in central Bohemia. During our survey, adults and juveniles of B. eremus were found within the trunk of declining Quercus spp., in the Sychrov castle park (near Mohelka River) in Bohemia. As confirmed by our morphological and molecular analyses, the presence of B. eremus seems to be widespread within country. The cerambycid Plagionotus arcuatus (L.) and the buprestid Chrysobothris affinis (Fabricius) collected from the same declining Quercus trees (Cermák et al. 2009) did not carry Bursaphelenchus.

Following the first report of B. eremus, three other species were recorded in the Czech Republic, that is, B. fungivorus Franklin \& Hooper, 1962 (Braasch et al. 2002), B. mucronatus Mamiya \& Enda, 1979 (unpublished data, in Braasch 2001) and B. hofmanni Braasch, 1998, which were all intercepted in imported coniferous wood (unpublished data, in Braasch 2001). However, no morphological description and no morphometric or molecular characterization was included in these reports. Due to the lack of information regarding the origin of the collected wood material, we were unable to trace their geographical location within the Czech Republic.

Bursaphelenchus vallesianus was found associated with declining P. sylvestris in both Moravia and Bohemia. This species had previously been reported to occur in the Moravia region (Gaar et al. 2006; Zouhar et al. 2006). Although B. vallesianus has repeatedly been associated with P. sylvestris in central Europe (CABI 2010), it has recently been reported from different regions of Eurasia, such as Turkey (Akbulut et al. 2008) and China (CABI 2010). The potential involvement of B. vallesianus on P. sylvestris decline in Valais (Switzerland) has been suggested (Polomski et al. 2008). Furthermore, some pathogenic potential of $B$. vallesianus was also demonstrated experimentally when 3-year-old $P$. sylvestris trees, under a drought stress situation, were inoculated with species (Polomski and Rigling 2010). Whether this species can be considered pathogenic 


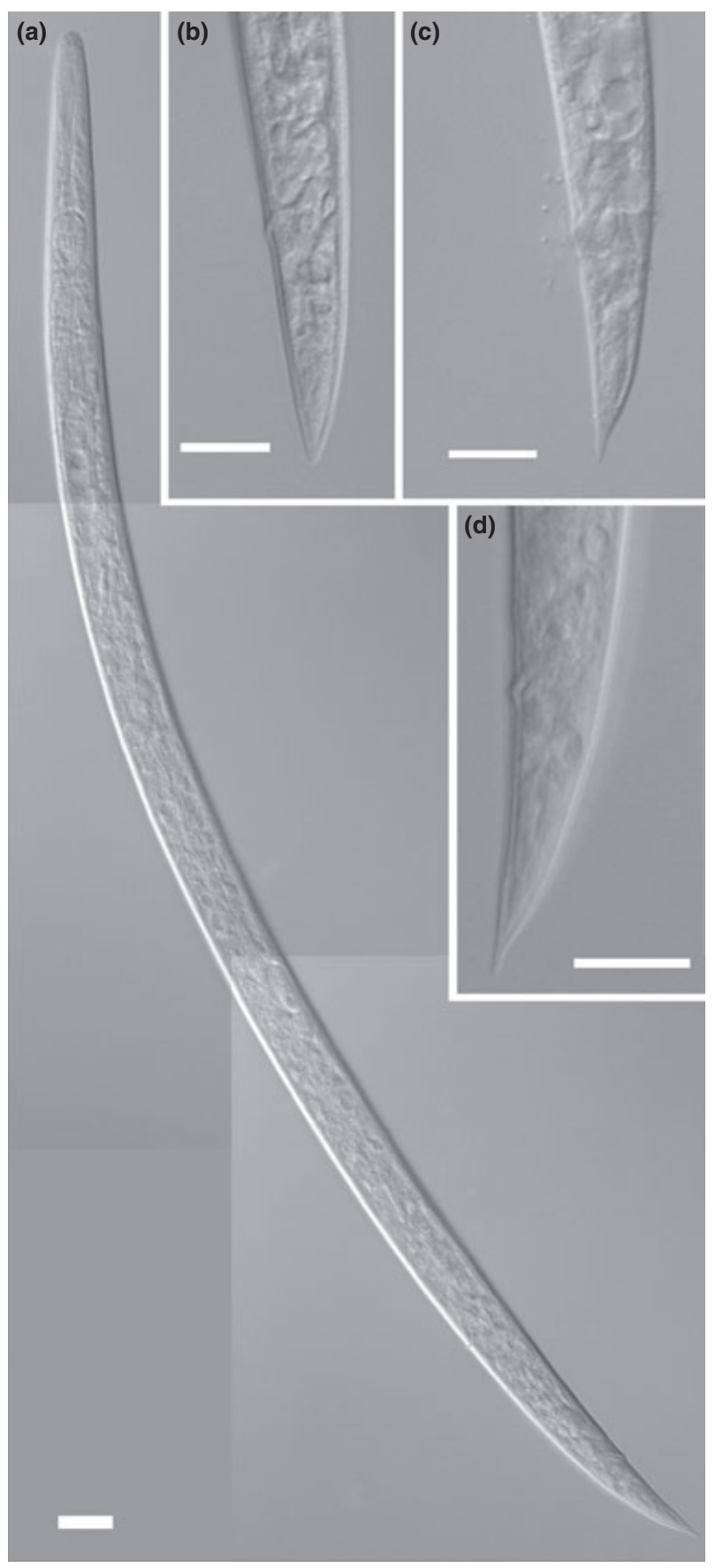

Fig. 5. Light micrograph of dauer juveniles of Bursaphelenchus pinophilus. (a) Whole dauer body. (b-d) Variation of dauer tails. Scale bars $=10 \mu \mathrm{m}$

and harmful to pine forests remains unclear. Although all trees surveyed during this study showed symptoms of decline, B. vallesianus occurred in only two trees. Due to the low number of individuals found on each tree, and occasional distribution, no correlation could be drawn between the declining pine trees and the presence of this species.

During our survey, B. pinophilus was found for the first time in the Czech Republic and it was associated with declining P. sylvestris, in two different areas of Bohemia. This species has been reported from Poland (Brzeski and Baujard 1997), Germany (unpublished data, in Braasch 2001), Portugal (Penas et al. 2007) and recently from Korea, where it was associated with dead Pinus koraiensis (Han et al. 2009). The sexdentati group of species has been showing a tight correlation with insects belonging to the Scolytinae (Ryss et al. 2005; Braasch et al. 2009). Our previous findings showed for the first time an association of $B$. pinophilus with its insect vector, the bark beetle P. bidentatus (Čermák et al. 2012).

Our survey results also enable us to report for the first time in the Czech Republic, B. borealis in association with the bark beetle D. autographus, which occurs under the bark of declining P. abies. D. autographus, which is considered a 
Table 4. Morphometrics of dauer juveniles of Bursaphelenchus borealis and B. pinophilus isolated from the bark beetles Dryocetes autographus and Pityogenes bidentatus, respectively. All measurements are in micrometre and in the format: mean \pm SD (range).

\begin{tabular}{|lcc|}
\hline & $\begin{array}{c}\text { Bursaphelenchus borealis (dauer juveniles } \\
\text { isolated from } D . \text { autographus) } \mathrm{n}=5\end{array}$ & $\begin{array}{c}\text { Bursaphelenchus pinophilus (dauer juveniles } \\
\text { isolated from P. bidentatus) } \mathrm{n}=8\end{array}$ \\
\hline $\mathrm{L}$ & $406.4 \pm 42.0(346-466)$ & $374.4 \pm 11.9(363-394)$ \\
$\mathrm{a}$ & $31.7 \pm 2.1(29.8-35.2)$ & $25.6 \pm 1.1(23.8-28.0)$ \\
$\mathrm{c}$ & $15.9 \pm 1.5(20.1-27.5)$ & $14.3 \pm 0.6(13.8-15.0)$ \\
$\mathrm{c}^{\prime}$ & $3.4 \pm 0.2(3.1-3.7)$ & $2.9 \pm 0.1(2.9-3.1)$ \\
Head - MB & $49.2 \pm 3.5(46.2-54.7)$ & $46.6 \pm 1.2(45.0-48.5)$ \\
Max. body diam. & $12.8 \pm 1.1(11.6-14.3)$ & $14.7 \pm 0.5(14.3-15.5)$ \\
Anal body diam. & $7.5 \pm 0.4(7.1-8.2)$ & $8.9 \pm 0.4(8.2-9.4)$ \\
Tail length & $25.7 \pm 2.4(22.5-28.9)$ & $26.2 \pm 0.7(25.0-26.7)$ \\
MB width & $6.5 \pm 0.2(6.2-6.8)$ & $7.4 \pm 0.5(6.5-7.8)$ \\
MB length & $11.3 \pm 0.2(11.0-11.6)$ & $13.5 \pm 1.1(11.3-14.7)$ \\
Genital primordium (GP) length & $15.0 \pm 2.1(12.7-19.0)$ & $19.1 \pm 4.3(12.0-23.6)$ \\
Head - GP & $257.7 \pm 36.7(204.4-314.0)$ & $247.0 \pm 25.1(217.0-297.0)$ \\
\hline
\end{tabular}

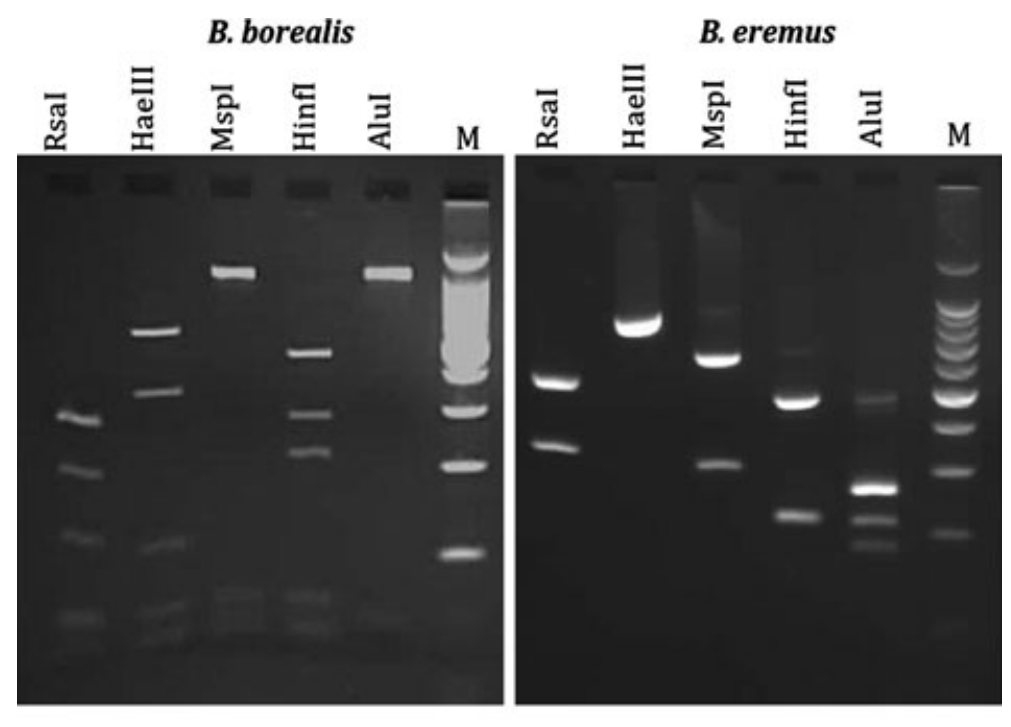

\section{B. pinophilus}

B. vallesianus

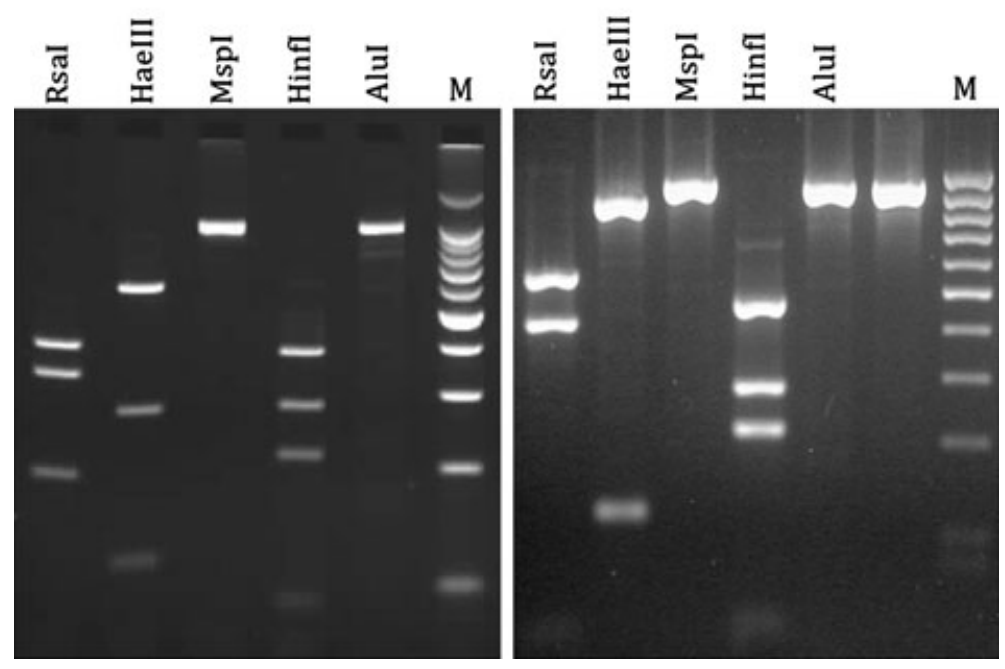

Fig. 6. ITS-RFLP profiles of B. borealis, B. eremus, B. pinophilus and B. vallesianus. The enzymes used for the restriction digest are indicated above the corresponding line. M: DNA size marker (100 bp). 
Palearctic species occurring abundantly from low to high altitudes of central Europe, has been reported before as the insect vector of B. borealis (Braasch et al. 1999). This insect species develops mainly under the bark of spruces (Picea spp.), and occasionally in some other conifers, feeding on heavily weakened, dying or felled trees that were previously attacked by more aggressive bark beetles (Postner 1974). Its preferential occurrence with the base or stumps of the tree, due to the favourable moist conditions (Pfeffer 1955), could also reflect the preferable habitat for B. borealis. After its original description from Russia (Magadan territory), in association with the vector Ips subelongatus Motschulsky (Korentchenko 1980), B. borealis has been occasionally reported for Germany (Braasch et al. 1999), in intercepted wood from Russia (Braasch et al. 2001) and associated with Pinus brutia Tenore in Cyprus (Braasch and Philis 2002).

During our survey of dying or symptomatic trees, special attention was also paid to the collected insects that are also known to vector Bursaphelenchus species. Most of the insects we collected belong to the subfamily Scolytinae, suggesting a strong association between these species and decaying trees. The number of associated nematodes with different species within the Scolytinae demonstrates a broader association of these insects with a different set of nematode genera, including two species of Bursaphelenchus. Within the Cerambycidae, only eight specimens of Monochamus galloprovincialis (Olivier), the insect vector of B. xylophilus in Portugal (Sousa et al. 2001), were captured, without any associated nematodes. Although Monochamus spp. are considered secondary forest pests, mainly associated with weakened or dying host trees (Evans et al. 2004), they assume great importance as they are the major insect carriers of B. xylophilus worldwide (Akbulut and Stamps 2012). In the Czech Republic, five species of the genus Monochamus have been reported, namely M. galloprovincialis, M. saltuarius (Gebler), M. sartor Fabricius, M. sutor (L.) and M. urussovi (Fischer), with both M. galloprovincialis and M. sutor representing the most widely distributed species (Sláma 1998). The wide distribution of species of the genus Monochamus within the Czech Republic reinforces the idea that a continuous plan for monitoring the main forests could be advantageous, because all the conditions for potential introduction and propagation of B. xylophilus are met in certain areas of the country. Up to know, and based upon the analysis of several hundreds of samples, the status of $B$. xylophilus in the country remains as being absent.

To summarize, to date seven Bursaphelenchus species have been reported to occur in the Czech Republic. Future surveys within other regions of the Czech Republic will generate a better knowledge of the full diversity and distribution of the genus Bursaphelenchus in the Czech forests.

\section{Acknowledgements}

This research was partly supported by an ERASMUS, Portugal-Czech Republic Cultural Agreement Programme (2007-2010), Czech Ministry of Agriculture, project number QF4156, the Ministry of Education of the Czech Republic, number MSM6046070901 and MSM 6215648902. P. Vieira and M. Mota were partially supported by the EC 7th Framework project REPHRAME (KBBE.2010.1.4-09, 'Analysis of the potential of the pine wood nematode (Bursaphelenchus xylophilus) to spread, survive and cause pine wilt in European coniferous forests in support of EU plant health policy'). The authors kindly thank to Kateřina Široká and Hana Orságová from the Division of Diagnostics Olomouc, State Phytosanitary Administration, for technical assistance.

\section{References}

Abelleira, A.; Picoaga, A.; Mansilla, J. P.; Aguin, O., 2011: Detection of Bursaphelenchus xylophilus, causal agent of pine wilt disease on Pinus pinaster in Northwestern Spain. Plant Dis. 95, 776.

Akbulut, S.; Stamps, W. T., 2012: Insect vectors of the pinewood nematode: a review of the biology and ecology of Monochamus species. For. Path. 42, 89-99.

Akbulut, S.; Elekcioglu, I. H.; Keten, A., 2008: First record of Bursaphelenchus vallesianus Braasch, Schonfeld, Polomski, and Burgermeister in Turkey. Turk. J. Agric. For. 32, 273-279.

Anonymous, 2007: EPPO standards: national regulatory control systems. EPPO Bull. 37, 219-220.

Anonymous, 2009: Report on forestry of the Czech Republic 2009. Prague: Ministry of Agriculture of the Czech Republic, pp. 113.

Běhalová, M., 2006: Recent surveys for Bursaphelenchus xylophilus in the Czech Republic. EPPO Bull. 36, 467-469.

Braasch, H., 2001: Bursaphelenchus species in conifers in Europe: distribution and morphological relationships. EPPO Bull. 31, $127-142$.

Braasch, H.; Philis, J., 2002: New records of Bursaphelenchus abietinus sp. in Cyprus. Nematol. Medit. 30, 55-57.

Braasch, H.; Metge, K.; Burgermeister, W., 1999: Bursaphelenchus-Arten (Nematoda, Parasitaphelenchidae) in Nadelgehölzen in Deutschland und ihre ITS-RFLP-Muster. Nachricht. Deutsch. Pflanzenschutz. 51, 312-320.

Braasch, H.; Tomiczek, C. H.; Metge, K.; Hoyer, U.; Burgermeister, W.; Wulfert, I.; Schönfeld, U., 2001: Records of Bursaphelenchus spp. (Nematoda, Parasitaphelenchidae) in coniferous timber imported from the Asian part of Russia. Forest Pathol. 31, 129-140.

Braasch, H.; Bennewitz, A.; Hantusch, W., 2002: Bursaphelenchus fungivorus - ein Nematode aus der Gruppe der Holznematoden im Pflanzsubstrat eines Gewächshauses und in Holz-und Rindenimport. Nachricht. Deutsch. Pflanzenschutz. 54, 1-4.

Braasch, H.; Burgermeister, W.; Gu, J., 2009: Revised intra-generic grouping of Bursaphelenchus Fuchs, 1937 (Nematoda: Aphelenchoididae). J. Nematode Morphol. System. 12, 65-88.

Brzeski, M. W.; Baujard, P., 1997: Morphology and morphometrics of Bursaphelenchus (Nematoda: Aphelenchoididae) species from pinewood of Poland. Ann. Zool. 47, 305-319.

Burgermeister, W.; Braasch, H.; Metge, K.; Gu, J.; Schröder, T.; Woldt, E., 2009: ITS-RFLP analysis, an efficient tool for differentiation of Bursaphelenchus species. Nematology 11, 649-668.

CABI, 2010: Bursaphelenchus vallesianus. Distribution Maps of Plant Diseases (October): Map 1084 (Edition 1081).

Čermák, V.; Gaar, V.; Orságová, H.; Foit, J.; Široká, K.; Tománková, T., 2009: The re-discovering of Bursaphelenchus eremus Rühm, 1956 (Nematodea, Parasitaphelenchidae) in the Czech Republic in 2008. In: Abstract of Šafránková, I.,Šefrová, H., Sborník abstraktů XVIII. Ceské a Slovenské konference o ochraně rostlin. 1 vydání Brno: MZLU v Brně, 2009. Czech Republic, 2009, pp. 140 (abstract).

Čermák, V.; Vieira, P.; Gaar, V.; Čudejková, M.; Foit, J.; Široká, Mota, M., 2012: Bursaphelenchus pinophilus Brzeski \& Baujard, 1997 (Nematoda: Parasitaphelenchinae) associated with nematangia on Pityogenes bidentatus (Herbst, 1783) (Coleoptera: Scolytinae), from the Czech Republic. Nematology 14, 385-387. 
Evans, H. F.; McNamara, D. G.; Braasch, H.; Chadouef, J.; Magnusson, C., 1996: Pest risk analysis (PRA) for the territories of the European Union (as PRA area) on Bursaphelenchus xylophilus and its vectors in the genus Monochamus. EPPO Bull. 26, 199-249.

Evans, H.; Moraal, L. G.; Pajares, J. A., 2004: Buprestidae and Cerambycidae. In: Bark and wood boring insects in living trees in Europe, a synthesis. Ed. by Lieutier, F.; Day, K. R.; Battista, A.; Gregoire, J. C.; Evans, H. F. Dordrecht: Kluwer, pp. 447-474.

Ferris, V. R.; Ferris, J. M.; Faghihi, J., 1993: Variation in spacer ribosomal DNA in some cyst-forming species of plant parasitic nematodes. Fund. Appl. Nematol. 16, 177-184.

Fonseca, L.; Cardoso, J. M. S.; Lopes, A.; Pestana, M.; Abreu, F.; Nunes, N.; Mota, M.; Abrantes, I., 2012: The pinewood nematode, Bursaphelenchus xylophilus, in Madeira Island. Helminthologia 49, 96-103.

Gaar, V.; Zouhar, M.; Douda, O.; Marek, M.; Nováková, E.; Rysánek, P., 2006: First occurrence of Bursaphelenchus vallesianus in the Czech republic. In: Abstracts of Pine wilt disease: a worldwide threat to forest ecosystems. International Symposium, 10-14 July, 2006. Lisbon, Portugal, 2006, pp. 62 (abstract).

Han, H.; Chung, Y. J.; Shin, S. C., 2009: First report of Bursaphelenchus pinophilus on Korean pine (Pinus koraiensis). Plant Dis. 93, 1.

Korentchenko, E. A., 1980: New species of nematode from the family Aphelenchoididae, parasites of stem pests of the Dahuran Larch. Zoologicheskii Zhurnal 59, 1768-1780.

Kubátová, A.; Novotný, D.; Prášil, K.; Mráček, Z., 2000: The nematophagous hyphomycete Esteya vermicola found in the Czech Republic. Czech Mycol. 52, 227-235.

Mota, M.; Braasch, H.; Bravo, M. A.; Penas, A. C.; Burgermeister, W.; Metge, K.; Sousa, E., 1999: First report of Bursaphelenchus xylophilus in Portugal and in Europe. Nematology 1, 727-734.

Penas, A. C.; Bravo, M. A.; Valadas, V.; Mota, M., 2007: Detailed morphobiometric studies of Bursaphelenchus xylophilus and characterization of other Bursaphelenchus species (Nematoda: Parasitaphelenchidae) associated with Pinus pinaster in Portugal. J. Nematode Morphol. System. 10, 137-163.

Pfeffer, A., 1955: Kůrovci - Scolytidae. Fauna ČSR. Svazek 6. Praha: ČSAV, pp. 324.

Polomski, J.; Rigling, D., 2010: Effect of Watering Regime on Disease Development in Pinus sylvestris Seedlings Inoculated with Bursaphelenchus vallesianus and B. mucronatus. Plant Dis. 94, 1055-1061.

Polomski, J.; Rigling, D.; Schweingruber, F., 2008: Development of external and internal symptoms in pine seedlings (Pinus sylvestris) due to inoculation with Bursaphelenchus vallesianus. In: Pine Wilt Disease: A Worldwide Threat to Forest Ecosystems. Ed. by Mota, M.; Vieira, P. Netherlands: Springer Science + Business Media B.V., pp. 335-344.

Postner, M., 1974: Scolytidae (= Ipidae), Borkenkäfer. S. In: Die Forstschädlinge Europas. Bd. II. Ed. by Schwenke, W. Paul Parey: Berlin, pp. 334-482.

Robertson, L.; Cobacho Arcos, S.; Escuer, M.; Santiago Merinos, R.; Esparrago, G.; Abelleira, A.; Navas, A., 2011: Incidence of the pinewood nematode Bursaphelenchus xylophilus Steiner \& Buhrer, 1934 (Nickle, 1970) in Spain. Nematology 13, 755-757.

Ryss, A.; Vieira, P.; Mota, M.; Kulinich, O., 2005: A synopsis of the genus Bursaphelenchus Fuchs (Nematoda: Parasitaphelenchidae) with a key to species. Nematology 7, 393-458.

Seinhorst, J. W., 1959: A rapid method for the transfer of nematodes from fixative to anhydrous glycerin. Nematologica 4, 67-69.

Sláma, M. E. F., 1998. [Long-horned beetles (Cerambycidae) of the Czech Republic and the Slovak Republic (Beetles-Coleoptera).], Krhanice: Milan Sláma, pp. 383.

Sousa, E.; Bravo, M. A.; Pires, J.; Naves, P.; Penas, A. C.; Bonifácio, L.; Mota, M., 2001: Bursaphelenchus xylophilus (Nematoda: Aphelenchoididae) associated with Monochamus galloprovincialis (Coleoptera; Cerambycidae) in Portugal. Nematology 3, 89-91.

Vrain, T. C., 1993: Restriction fragment length polymorphism separates species of the Xiphinema americanum group. J. Nematol. 25, 361364.

Whitehead, A. G.; Hemming, J. R., 1965: A comparison of some quantitative methods of extracting small vermiform nematodes from soil. Annals Appl. Biol. 55, 25-38.

Zouhar, M.; Gaar, V.; Douda, O.; Marek, M.; Nováková E., ; Ryšánek, P., 2006: First occurrence of Bursaphelenchus vallesianus in the Czech Republic. In: Abstracts of the Proceedingsof XVII. Czech and Slovak Plant Protection Conference, 12-14 September, 2006. Czech Agricultural University, Prague, Czech Republic, pp. 426-428 (abstract). 